\title{
Conclusion: Changes in Southern Political Party Organizations and Activists
}

\author{
Charles Prysby and John A. Clark
}

\begin{abstract}
In this concluding article, we recap the findings reported in the preceding articles and place them in a broader regional context. We focus on two broad themes: conflict and consensus between and within the parties and changes in the party organizations themselves. We close by identifying possible trends that will influence grassroots parties in the South over the coming decade and beyond.
\end{abstract}

\section{Introduction}

When V.O. Key wrote Southern Politics in State and Nation (1949), the "Solid South" was dominated by the Democratic Party. The most important election in most locales was the Democratic primary, and the winner of that contest usually faced at most token opposition in the general election. Democratic candidates viewed permanent party organizations as potential obstacles to their chances in future elections, so local parties in most states were more likely to function as election boards charged with conducting the Democratic primary than as campaign organizations. Republicans organized to dispense federal patronage for those occasions when the party controlled the White House, but the GOP did not regularly contest elections in most southern states. Under these conditions, then, there was little reason for either party to create organizations at the local level.

Much has changed since Key's time. The Democratic dominance of presidential elections began to weaken in the 1950s and was replaced with a Republican tilt by the 1980s (Black and Black 1992). Similar shifts in partisan identification and elections for lower level offices followed at somewhat different paces in different states. By 2000, most states had achieved levels of intraparty competition that would have been difficult for Key to imagine. The change in competitiveness has contributed greatly to the development of party organizations (Key 1949; Crotty 1971), which in turn has allowed more candidates to be competitive in more places. ${ }^{1}$

Our study of southern grassroots political party activists was conducted in the context of this changing party competition. The authors have pursued

CHARLES PRYSBY is a professor of political science at the University of North Carolina at Greensboro. JOHN A. CLARK is an associate professor of political science at Western Michigan University. We are grateful to Brian Schaffner for his insightful suggestions on an earlier draft.

The American Review of Politics, Vol. 24, Summer, 2003: 213-223

C2003 The American Review of Politics 
two major lines of inquiry. One deals with patterns of conflict and consensus within and between political parties. We are interested here in the nature and extent of the cleavages between Democratic and Republican activists and in the tensions and divisions within each of the parties. The second major line of inquiry is into the strength of the political party organizations at the county level. We are concerned here both with the extent to which political party activists are involved in their local party organizations and with the perceptions and orientations that these activists have regarding their party organizations. Both lines of inquiry can be followed by analyzing the 2001 data and comparing the 2001 patterns with those found in the data collected by the 1991 Southern Grassroots Party Activists Project.

The preceding articles analyze these questions for each of the eleven southern states. While variations can be found across the states, there are a number of patterns that exist in most if not all of them, and we attempt to summarize these overall patterns in this concluding article. In considering our findings, it is worthwhile to remember that the activists surveyed in this study represent Republican and Democratic leaders at the county level. They are county chairs, vice chairs, and other members of the county party executive committees. As local party leaders, their attitudes and behavior are important in defining the nature of the party organization.

\section{Inter and Intra-Party Conflict and Consensus}

One of the most obvious developments revealed by these data is the significant ideological polarization of southern political party activists over the past ten years. ${ }^{2}$ Republican activists, who already were fairly conservative in 1991, have become even more so, with high percentages identifying themselves as very conservative. Very few Republicans now call themselves moderate; almost none say that they are liberal. While Republicans have been moving to the right, Democrats have been shifting to the left. In 1991, a sizable number of Democratic party activists said that they were conservative. Far fewer do so now. Even with this shift, Democratic activists are a more ideologically diverse group, at least compared to Republicans, as also was the case in 1991. Democratic activists have ideological identifications that currently range from very liberal to moderate, with less than one in five adopting a conservative label. Somewhat larger proportions of conservative Democrats are found in the Deep South states and Arkansas.

An analysis of the policy orientations of the activists reinforces the above conclusion. Republicans hold strongly conservative positions across a wide range of issues. They stand solidly against legalized abortion, handgun control, hiring preferences for racial minorities, laws to prohibit job discrimination against gays, and more government regulation of managed health 
care. They strongly support reductions in government services and spending, a flat federal income tax, some sort of school prayer, school vouchers, and capital punishment. In terms of budgetary priorities, Republicans overwhelmingly support increased defense spending (and note that this survey was conducted prior to September 11, 2001), and decreased spending on welfare programs. On some spending matters, such as education or social security, they have more mixed views, however.

In contrast, Democratic party activists are less sharply defined ideologically. On some issues, such as abortion or school vouchers, Democrats in most states seem clearly liberal. On other issues, such as school prayer or affirmative action, they often have more mixed views, with their center of gravity leaning toward the right. When it comes to spending on many domestic programs, such as education, environmental protection, or health care, Democrats seem solidly in favor of more spending. On other spending issues, such as defense or welfare, they have very mixed views.

To the extent that we are able to compare the current positions of Democratic and Republican party activists with the positions held in 1991, the pattern matches the finding for ideological identification. That is, Democratic and Republican grassroots party activists are more clearly divided on policy issues now than they were ten years ago. For example, abortion was an issue that divided Republican activists in many states in 1991. Now there are far fewer pro-choice voices in the local GOP organizations. At the same time, Democratic activists have moved in the opposite direction on this issue. The result is a Democratic Party organization that, at least in terms of activists, is clearly on one side of the abortion issue and a Republican Party organization that is clearly on the other side.

The growing polarization of the party activists raises an important question. Has either group of activists moved so far from the center of public opinion that they run the risk of conveying an extremist image to the electorate? This is a difficult question to answer (see Breaux, Shaffer, and Cotter 1998; Maggiotto and Wekkin 2000). In fact, it is not even clear which set of party activists is further from the mid-point of public opinion. The southern electorate is widely viewed as conservative, so we might think that the clearly conservative orientation of Republican activists would put them closer to the views of the average voter. However, while the southern electorate is more conservative than the non-southern electorate, the difference on specific issues frequently is not all that great. Many southern voters are only somewhat conservative or even moderate in their political orientations. These voters might easily see Republican activists as too far to the right. Similar uncertainty surrounds the assessment of the ideological positions of Democratic activists. In an area where liberals almost seem unwelcome, Democratic activists might be seen as too far to the left, but the moderate 
nature of their liberalism could place them no further than Republican activists from the average voter. Both Democratic and Republican activists appear to be some distance from the median voter, and it is unclear which group of activists is further away. What we can safely say is that the differences between elites and masses has widened in the South. That, of course, is a development that could have important consequences in future elections.

Another way to approach the question of the policy views of activists versus the electorate is to examine the extent to which either group of activists is highly purist. By purist, we refer to orientations on the part of activists that place ideological purity ahead of electoral success. Purists are much less willing than are pragmatists to compromise on issues in order to win more votes. ${ }^{3}$ Republican activists in 2001, as in 1991, are more purist than their Democratic counterparts, at least in the states where this orientation was examined. However, while Republicans are more purist, they are not extremely so, and it probably is unfair to characterize them as ideologically rigid. Still, the combination of many activists being strongly conservative and fairly purist raises at least the potential for problems within the party as it attempts to win elections.

The activists of each party are clearly more cohesive in ideological and issue terms now than they were ten years ago. This is evidenced not only in the specific issue orientations held by the activists but also in more general expressions of loyalty toward the parties. Both Democratic and Republican activists express high levels of identification with and loyalty to their national, state, and local parties. At least among Democrats, this is a shift from 1991. While there is greater cohesion now than in 1991, both Democratic and Republican activists are far from a homogeneous group in their political thinking. In fact, both Democratic and Republican activists perceive a substantial amount of factionalism within their party organization. The extent and nature of this perceived factionalism varies across the states, but the general pattern is that: (a) the activists see their party as somewhat less factionalized now than it was ten years ago; and (b) the Democrats see somewhat more factionalism in their party than Republicans do in theirs.

One basis for factionalism in the Democratic Party is race. The tensions involved in maintaining a biracial coalition are evident in the attitudes of the activists. For example, black and white Democrats tend to divide fairly sharply on the question of minority hiring preferences. Factionalism based on race need not involve concrete policy questions. Symbolic issues, such as the Confederate battle flag, are capable of creating divisions. Indeed, purely local issues, such as the composition of the police force or filling key executive positions like county manager, can take on a race-related dimension seen as important by party activists. 
The Democratic biracial coalition has been critical for the party's success for some time (Black and Black 1992; Hadley and Stanley 1998). What has changed recently, however, is the increasing presence of blacks as important activists within the local Democratic organizations. In 1991, blacks were poorly represented among the leadership of the county Democratic Party organizations in most states. Much has changed in ten years. Every state analysis reports an increase in black Democratic activists. In most cases, the increase is large. In Mississippi, for example, almost half of the Democratic respondents were African American, as were nearly a third of the executive committee members in South Carolina and Louisiana. This greater representation of blacks at the grassroots level has the potential for making divisions on race-related issues more divisive within the local party organizations. On the other hand, it might also have the potential to cement a biracial coalition by promoting dialogue among local party elites of both races. Which potential is realized will have to be determined by future research.

Divisions within the Democratic Party organizations are not solely along racial lines. Even among whites, moderate and liberal Democrats divide over a number of issues. As we have seen, these divisions have been reduced over the past decade. To the extent that a more cohesive party organization emerges, it should be regarded as a development that strengthens the local party organizations. However, there is the danger that as the activists become more liberal, moderate individuals may feel less comfortable within the party organization and therefore choose not to be involved. If carried too far, such a development could alienate party activists from much of the electorate and even from Democratic officeholders and candidates, most of whom are able to win only by appealing to more moderate swing voters. Of course, the same questions could be raised for Republican activists. As they become a more cohesive conservative group, they too may lose their moderate voices, a development that could have similarly unfortunate consequences if carried too far (see Aldrich 1995, 163-193).

Although Republicans are more cohesive than Democrats, there are divisions among Republican activists in every state. In most states, one important cleavage within the party is between those who are strong supporters of the Christian Right and those who have at best mixed views of this movement. This division shows up particularly on social issues, such as abortion, school prayer, school vouchers, and proposed prohibitions of discrimination against gays. These contentious social issues have the potential to divide Republicans who are conservative on economic issues but moderate on social issues from Republicans who are both very conservative on these social issues and also highly concerned about them. In fact, these data suggest that economically conservative but socially moderate Republicans have 
come to play a less important role in their local party organizations over the past decade, as evidenced by the decline in Republican activists who favor abortion rights, for example.

The movement toward local party organizations whose activists are both more clearly divided on issues and at least somewhat more cohesive in their political orientations is a development that should please proponents of a more responsible political party system (American Political Science Association 1950). Of course, grassroots party activists are only one segment of the party. Clearly, the behavior of candidates and officeholders is more important in defining how responsible the parties are. Still, to the extent that party activists contribute to the party image, increased ideological division between the two parties and decreased divisions within each party are notable developments. It appears that the creation of a competitive two-party system throughout the South has influenced the composition of the party organizations in some significant ways.

\section{Organizational Strength}

Nearly 20 years ago, a team of political scientists examined a national survey of county party chairs and asked the question, "Whither the local party?" (Gibson et al. 1985). At that time, the region with the weakest local parties was the South. State rankings of local party organizational strength revealed only three southern states where the Democrats and only one where Republicans were ranked in the top half. Five of the weakest ten in each party were located in the South. ${ }^{4}$ Our data from 2001 do not allow us to make comparisons to other regions of the country, but we can safely say that local party organizations in the South are more numerous, and more meaningful, than they were in the late 1970s. Moreover, our comparisons with the first Southern Grassroots Activists Project in 1991 give strong support for the idea that grassroots parties have at the very least not weakened across the decade of the 1990s.

One way to measure the strength of party organizations is to look at the tasks they perform during the campaign season. The 1991 study showed that Democratic activists were more involved in local campaigns, while Republicans focused their attention on national elections. The same gap is still apparent, but it has grown smaller over the past decade. In some states, this was due to increased GOP involvement at the local level as the party developed more and better candidates to support. Likewise, many Democrats may have found it easier to support the presidential candidacy of Al Gore in 2000 than Michael Dukakis in 1988. Other patterns of activity appear, though. For instance, Alabama Republicans reported less activity overall (especially in state elections) in 2001 than they had in 1991. 
When questioned about specific campaign activities, levels of activism were generally as high or higher in 2001 than in 1991 in virtually every state. Patterns of partisan difference are varied, however. Democratic activists were more likely to report performing various activities than Republicans in Mississippi, North Carolina, and Louisiana, while Republicans held the edge in Arkansas. The pattern was mixed in Alabama, with more Republicans performing some activities and more Democrats performing others. There were few differences across party chairs in Tennessee, but members of the GOP county executive committees were more active than their Democratic counterparts.

In sum, our 2001 study shows higher levels of campaign activity on the part of these organizational leaders. Activity performance is not the only measure of organizational vitality, and we caution reading too much into these differences. We do not know the extent to which respondents were spending time on these tasks, for example, only that they claim to have done them at least once in the previous election cycle. Still, vital party organizations provide a variety of services to candidates, whereas moribund organizations do not (Burrell 1986; Gibson et al. 1985). In this area, at least, southern party organizations are involved and active.

Another way to gauge the strength of an organization is to see how united its members are in support of the organization and its goals. Because political parties in the United States are so decentralized, one level of the party may not speak for others. In 1991, Republican grassroots activists had stronger ties to their national parties than Democrats, but Democrats felt a stronger attachment to their state parties (Clark and Lockerbie 1998). As the South's politics become more like those in the rest of the nation, the gap in evaluations of the national and state organizations becomes smaller. Republican support for the party's presidential candidates was virtually unanimous in all states in the elections preceding our surveys (George H.W. Bush in 1988 and George W. Bush in 2000), while Democrats found Al Gore to be much more palatable in 2000 than Michael Dukakis was in 1988. Still, a substantial portion of Democratic activists defected in the most recent election.

The higher level of disagreement evident in Democratic voting is reflected in the level of factionalism reported by grassroots party officials. In every state but one, Democrats reported higher levels of factionalism in both their state parties and their county parties than did Republicans. The margins in some states were considerable. For example, 70 percent of Mississippi Democrats claimed that the level of factionalism in their state was at least moderately high, compared to only one third of the GOP activists in the state. Louisiana was the one exception: two thirds of the activists in each party reported high levels of factionalism there. ${ }^{5}$ As noted above, the saving 
grace for Democrats may be that their party's leaders seem to value party unity - that is, working to unite different factions - more than Republicans, although this may be nothing more than a necessary response to a difficult situation.

As a final measure of organizational strength, we asked party activists to evaluate the change in their county party's strength over the last ten years on a number of different dimensions. In terms of their overall assessment, Republican activists clearly saw improvement in their parties. Three out of four GOP leaders in every state thought the county party organization had become stronger, while one in ten or less thought the organization had become weaker. Differences among Democrats were more substantial. Majorities in every state but Arkansas thought the party had gained strength. As many as one third of the Democrats in North Carolina thought their county organization had lost strength, with double-digit agreement across the region. Thus, while Democrats were more pessimistic about the changes taking place in their local organizations, many saw improvements taking place within the party.

We realize that these evaluations of party change are subjective and may not reflect actual changes in county organizations. Moreover, activists in both parties might be comparing their organizations to the opposition, which is a different point of reference than the question implies. Still, the patterns in 2001 are consistent with those present in the earlier 1991 study. Taken together, they reveal almost two decades of perceived improvement on the part of Republicans, while many Democratic activists view their organizations as at best maintaining the status quo. These perceptions no doubt reflect GOP gains in local elections; a successful election cycle can do wonders for morale in the local organization. To the extent that they reflect real improvements, however, they suggest additional Republican success in future elections. Democratic efforts to stem the GOP tide may well depend on their ability to infuse their local organizations with new life.

\section{Looking to the Future}

The 1991 Southern Grassroots Activists Project provided a baseline from which to examine local party organizations and activists in the South. Our 2001 follow-up survey allows us to examine changes that have taken place over the decade of the 1990s. These articles have focused on two lines of inquiry: conflict and consensus within and between the parties, and changes in the strength of party organizations at the local level. Other aspects of our data will be explored in subsequent publications.

What changes might be expected over the next ten years? Certainly the trends identified here, most notably the ideological polarization of party 
activists, bear watching. Successful statewide candidates in both parties have assembled multiracial or multiethnic coalitions by appealing to moderate voters with consensual issues like economic development and education. Will a more extreme activist base limit the ability of candidates to campaign toward the center? Likewise, the ability of both parties to recruit and retain new activists will be necessary to provide continued energy to perform party activities tempered by experience to perform them efficiently. Can the Republicans maintain their trajectory of organizational improvement (as identified by party activists)?

We prefer to leave prognostication to others, but we can point to two areas that can heavily influence grassroots party organizations. The first is partisan competition. Republicans dramatically improved their standing in the congressional and state legislative chambers of most states in the South between 1991 and 2001. Much of that change came early in the decade, however, and Democrats were able to stem the GOP tide as the 1990s drew to a close (especially in the 1998 elections). Will the region remain competitive? Or will the Republican gains continue until the formerly solid Democratic South is dominated by Republicans at all levels and in all states? A competitive equilibrium is likely to enhance the role of party organizations. As each vote becomes more important, the willingness of candidates to take advantage of the economies of scale offered by the party is likely to grow (Schlesinger 1985; Aldrich 1995). If one party becomes dominant, on the other hand, we may see the parties revert to the moribund condition that V.O. Key (1949) described.

A second trend that will affect local party organizations involves the system of campaign finance. State and local parties benefited from the laws in place in the 1980s and 1990s, and nowhere more than in the South. What will be the impact of recent reforms designed to reduce the flow of "soft money"? How might things change given the subsequent litigation provoked by the reforms? Remarkably, we see potential advantages for local parties under either scenario. ${ }^{6}$ The legislation passed in 2002 was designed primarily to limit the flow of money to be used for television advertising by the national parties and interest groups. Still, a substantial sum ends up supporting state and local party organizations and their candidates. A reversion to the pre-2002 laws would allow these uses to be continued. If, in contrast, the new soft money ban is upheld, the national parties will be prohibited from airing expensive advertisements. State and local parties, on the other hand, are regulated by state laws. They may become an even more attractive outlet for contributors who wish to influence political outcomes.

Regardless of how events unfold, we remain convinced that political parties remain worthy of attention from scholars and practitioners. No doubt the activists in our survey would concur. Why would they devote their time 
and money to organizations in which they had neither confidence nor interest? Perhaps another round of data collection in 2011 will show how well their confidence has held up. Whether or not such a project takes place, the South remains a valuable arena for the study of political change.

\title{
NOTES
}

\begin{abstract}
${ }^{1}$ In addition to changes in competition, changes in the system of campaign finance have contributed to the development of party organizations in the South and elsewhere. The Federal Election Campaign Act was amended in 1979 to allow the national parties to collect large sums of money for "party-building" activities. Much attention has been devoted to the use of "soft money" for television ads in recent election cycles. The original intent of the 1979 reforms, to foster the development of state and local party organizations and to support grassroots campaign activities, has gone largely unnoticed (but see Biersack 1996; La Raja 2003).

${ }^{2}$ It remains an open question whether the polarization results from an influx of new activists who hold less moderate views or a change in the views of some longtime activists across the decade of the 1990s (Stone, Rapoport, and Abramowitz 1990; Herrera 1995).

${ }^{3}$ The distinction between purists and pragmatists is found throughout the literature; see Prysby (1998) for a review. Others have adopted different labels like "amateur" and "professional" (Clark and Wilson 1961) or "purists" and "politicians" (Wildavsky 1965) to describe these viewpoints.

${ }^{4}$ Gibson and his colleagues (1985) used a complex measure of organizational strength that included campaign activity, programmatic activity, and organizational maintenance. Only a few of the items they used to create this measure were included in our survey.

${ }^{5}$ Louisiana's unusual electoral system might account for its higher levels of factionalism. In other states, party leaders attempt to build unity around their nominees in the general election campaign. Louisiana bypasses the nomination phase, thus allowing internal divisions to fester.

${ }^{6}$ For a more extensive analysis of the impact of these reforms on state and local parties, see La Raja (2003).
\end{abstract}

\section{REFERENCES}

Aldrich, John H. 1995. Why Parties? Chicago: University of Chicago Press.

American Political Science Association. 1950. Toward a More Responsible Two-Party System. New York: Rinehart \& Co.

Biersack, Robert. 1996. The Nationalization of Party Finance, 1992-1994. In The State of the Parties, 2nd ed., eds. John C. Green and Daniel M. Shea. Lanham, MD: Rowman and Littlefield.

Black, Earl, and Merle Black. 1992. The Vital South. Cambridge: Harvard University Press.

Breaux, David, Stephen D. Shaffer, and Patrick Cotter. 1998. Mass/Elite Linkage. In Party Organization and Activism in the American South, eds. Robert P. Steed, 
John A. Clark, Lewis Bowman, and Charles D. Hadley. Tuscaloosa: University of Alabama Press.

Burrell, Barbara C. 1986. Local Political Party Committees, Task Performance, and Organizational Vitality. Western Political Quarterly 39:48-66.

Clark, John A., and Brad Lockerbie. 1998. Split-Partisan Identification. In Party Activists in Southern Politics: Mirrors and Makers of Change, eds. Charles D. Hadley and Lewis Bowman. Knoxville: University of Tennessee Press.

Clark, Peter B., and James Q. Wilson. 1961. Incentive Systems: A Theory of Organizations. Administrative Science Quarterly 6:129-166.

Crotty, William J. 1971. Party Effort and Its Impact on the Vote. American Political Science Review 65:439-450.

Gibson, James L., Cornelius P. Cotter, John F. Bibby, and Robert J. Huckshorn. 1985. Whither the Local Parties? A Cross-Sectional and Longitudinal Analysis of the Strength of Party Organizations. American Journal of Political Science 29:139-160.

Hadley, Charles D., and Harold W. Stanley. 1998. Race and the Democratic Biracial Coalition. In Party Activists in Southern Politics: Mirrors and Makers of Change, eds. Charles D. Hadley and Lewis Bowman. Knoxville: University of Tennessee Press.

Herrera, Richard. 1995. The Crosswinds of Change: Sources of Change in the Democratic and Republican Parties. Political Research Quarterly 48:291-312.

Key, V.O., Jr. 1949. Southern Politics in State and Nation. New York: Alfred A. Knopf.

La Raja, Ray. 2003. State Political Parties after BCRA. In Life After Reform: When the Bipartisan Campaign Reform Act Meets Politics, ed. Michael Malbin. Lanham, MD: Rowman and Littlefield.

Maggiotto, Michael A., and Gary D. Wekkin. 2000. Partisan Linkages in Southern Politics. Knoxville: University of Tennessee Press.

Prysby, Charles. 1998. Purist versus Pragmatic Orientations. In Party Organization and Activism in the American South, eds. Robert P. Steed, John A. Clark, Lewis Bowman, and Charles D. Hadley. Tuscaloosa: University of Alabama Press.

Schlesinger, Joseph A. 1985. The New American Political Party. American Political Science Review 79:1152-1169.

Stone, Walter J., Ronald B. Rapoport, and Alan I. Abramowitz. 1990. The Reagan Revolution and Party Polarization in the 1980s. In The Parties Respond: Changes in the American Party System, ed. L. Sandy Maisel. Boulder, CO: Westview.

Wildavsky, Aaron. 1965. The Goldwater Phenomenon: Purists, Politicians, and the TwoParty System. Review of Politics 27:386-413. 
